\title{
The Outcast as a Mirror
}

\author{
By Michal Quigley \\ Spring 1993 Issue of KINEMA
}

\section{AGNES VARDA'S VAGABONDE: THE OUTCAST AS A MIRROR}

In 1985 French filmmaker Agnès Varda released what is considered by many to be her seminal work, Vagabonde $^{(1)}$ (Sans toit ni loi). The film represents over thirty years of experimentation with narrative structure and character development. Varda, who has always been fascinated with the audience's participation in the production of meaning, has created a film in which the reactions of secondary characters build a portrait of an enigmatic woman.

The director invites the audience to participate in uncovering of the "mystery" surrounding the life of a dead woman. On the surface, Vagabonde is a deceptively simple story. The film opens with the image of a frozen female corpse and a narrator (Varda) tells the audience that what follows are interviews with the people who knew her in the last weeks of her life. Through interviews and flashbacks the viewer learns how this young woman ended up in a ditch, but not why she started her solitary journey. The film's main concern is the reaction of people to the drifter, not her psychology. Varda uses other people's memories to construct an image of the drifter.

The following is an excerpt from a larger two-part study entitled Agnès Varda's Sans toit ni loi: A Solitary Journey.

FROM THE OUTSET, Varda establishes that she is using the accounts of witnesses to build a portrait of Mona, but as the film progresses it becomes evident that these interviews reveal more about the witnesses than the drifter. Each interview portrays a certain social view of what it is to be a drifter, not necessarily an accurate picture of who this particular drifter, Mona, is. Therefore, according to Varda, the film is: "More than just Mona who always eludes us, who is too reserved, too dosed, the film addresses 'the Mona effect' on those she came in contact with and inevitably affected. She is a catalyst, someone who forces others to react and adjust themselves in relation to her." ${ }^{(2)}$

Mona has five significant relationships throughout the film. She has two female "friends," Madame Landier and Yolande, two lovers, David and Assoun, and one intellectual partner, the Goatherd. Through these encounters, Varda explores Mona's capacity for emotional warmth, her intelligence, and her independence, but more explicitly these relationships explore the other people's views of Mona and who she "should" be. The testimony offered by the participants in these longer encounters is intercut with descriptions of Mona offered by other witnesses. In an interview with Barbara Quart during Vagabonde's New York premiere in 1986, Varda described her intentions as: "I like to see how her "no" [her rejection of society] opposed to the society gets reactions in such different ways according to who is meeting her. So by trying to capture more or less, less rather than more, who she was and what was in her mind, since we go through other people's reactions, we discover more about them than about her." ${ }^{(3)}$

The first witnesses are the workers in the vineyard where Mona's frozen body is found. One man offers sympathy for the dead woman, and tells the police that the purple stain on her is from being thrown into a wine vat in the nearby village. The next witness to describe Mona is Paulo who speaks of her to his friend. According to Paulo, he and his friend missed a golden opportunity when they saw Mona naked bathing in the sea because "a girl all alone is easy." The next cut shows Mona striding along the highway. A trucker picks her up, but when she declines his invitation to use the bed in the back, he kicks her out. The truck driver then acts as Mona's witness to his companion, and describes Mona as cute but "a pain in the ass." The trucker's story prompts the other man to recall finding a woman who was sleeping like an "angel" in one of the summer bungalows he was tearing down. In the three separate representations, all given equal weight, Mona has been described as a potential victim for being on her own, a pain for refusing sex, and as a sleeping angel.

Mona is a drifter, an outsider, and as such it is her role "... to provoke self-examination and doubt in the 
minds of those who 'belong."' (4) Her presence affects middle-aged housewives, school girls, truckers, mechanics, construction workers, academics, and domestics. Each reacts to her in a way that is indicative of her or his social position in the community. For example, a young farm girl helps Mona fill her water bottle at the family pump and later, during a family dinner, she tells her parents she wants to be free like the camper. When her mother asks who would make her dinner every night, the girl quietly replies, "At times it would be better not to eat." To this girl, who lives a sheltered life with her parents in a tiny village, Mona represents the freedom to go where she pleases without answering to anyone, a life full of excitement. Other parents worry that their daughter will turn out like Mona. In reference to Mona, a wife tells her husband, "She's got character. She knows what she wants. Marry the wrong man and you're stuck for life. I liked that hippy." To this middle-aged matron, Mona represents the freedom of choice. From these short observations on Mona, frequently given by witnesses who appear only once and are not involved in any of the more complex social relationships in the film, a complete range of views on Mona is expressed.

The testimonies of those who had significant relationships with her during the last few weeks of her life also illustrate societal views. Mona's two "friends," Madame Landier and Yolande, approached her for personal reasons. Yolande spotted Mona asleep in David's arms and developed a fantasy regarding the nature of their pure love, the type of love for which she yearns. When she finds Mona, Yolande is anxious to take care of her, but Mona is capable of taking care of herself, and, in the meantime, demonstrates that Yolande has created the limitations of her own existence. Madame Landier was tempted to ask Mona to get out of her car after she picked her up because the drifter smelled so foul, but out of politeness she let her stay in the warm car and gradually grew accustomed to her odour. She treats Mona like a great sociological experiment, and tries to understand her by asking questions. At one point she even asks her assistant, Jean-Pierre, if he wants to have a look at Mona while she waits in the car.

The first "friendship" dissolved because Yolande was jealous of Mona and considered her ungrateful. Yolande, an unhappy, lovesick domestic, was initially attracted to Mona because, to Yolande, she represented some sort of alternative paradise. After spying them asleep in one another's arms, Yolande thinks that David and Mona live in blissful love. She projects her image of the ideal relationship upon them, and, thereafter, her own relationship falls short. When she sees Mona hitchhiking, Yolande jumps at the opportunity to meet her and takes her home. The next morning Yolande tells Mona "You can keep me company. I'm so lonely." Starved for affection and connection, Yolande gets neither from her lover or her employer, she takes in a complete stranger to fill the void.

During the short time Mona is alone in Tante Lydie's house (the house where Yolande considers herself to be no more than a blue housecoat and a feather duster) Mona establishes a friendship with Tante Lydie and proves that Yolande's life of subservience is self-imposed. Seeing Mona laughing and carrying on with her boss enraged Yolande because in one afternoon Mona broke the boundaries Yolande had established for herself. Instead of staying quietly away from Tante Lydie and being Yolande's pet, Mona continued to do as she pleased. She neither needs nor cares about the things Yolande has done for her.

Yolande has always tried to please. In a little song her uncle sings about her, he calls her "one of the servants," "helpful," and describes her as always trying to look fashionable. She lives to serve her boss and to pursue ultimate love. Mona's behaviour is completely in opposition to everything Yolande is. She does not pursue affection. She never tries to be helpful, and she certainly does not care whether she looks "attractive" or not. By being so different, Mona challenges Yolande's sense of control over her situation. She has grown to accept her role of under-appreciated worker and lover and enjoys the sense of control this position gives her (everyone "needs" her to work so hard), but Mona's arrival unbalances her routine and threatens her sense of control. Yolande cannot accept this challenge and sends Mona away.

The second "friendship" ends because Madame Landier decides that it is time for Mona to get out of her car. During the course of their relationship Madame Landier looks after Mona but expects nothing in return. She picks her up and drives her around for a short time, but when she has to get back to her life, Madame Landier drops Mona off at the side of the highway. Varda describes Madame Landier as the only person who acts naturally around Mona. Mona never asks Madame Landier any questions about her personal life, but "... the other one [Madame Landier], because of her academic background, is sort of used to ask questions... It's almost professional." (5) Varda thinks she represents the most "natural" relationship anyone has with Mona 
because "... she knows she won't take the girl home, so she buys her food, she gives her money, and she says bye-bye.... She has the situation in hand. She won't adopt the girl."(6)

Madame Landier and Mona are societal opposites. Madame Landier has a career (she is a professor of agronomy). She has a home. She is clean and well fed. While she and Mona travel together, she discovers that Mona used to be a stenographer, has her high school diploma, that she hated her bosses, and now does not have the right "look" for most jobs. After smuggling Mona some food and champagne from a conference where she is lecturing, Madame Landier asks the drifter why she dropped out. Ever enigmatic, Mona simply responds that "Champagne on the road is better."

Madame Landier is a specialist on the disease that is scourging the region's plane trees and while they travel to the affected sites she describes the disease to Mona. The hours that they spend driving in her car are heaven for Mona. She is warm. She is moving and there is music on the radio. When Madame Landier drops her off, Mona is disappointed but understanding. Madame Landier has treated Mona like one of her research projects. She asked her questions, but sought not to alter her situation, and dismissed her from her life when the research was completed. Later, in a moment of crisis, Madame Landier has a vision of Mona and becomes worried about her. She feels guilty for not doing more than she did for the young drifter.

The attitudes of Mona's two female "friends" are paralleled in her two lovers, David and Assoun. David, like Yolande, developed a vision of Mona to meet his expectations while Assoun, like Madame Landier, accepted Mona as she was, but eventually was forced to reject her. Mona and David spent a few days together She moved into his "squat" (the abandoned chateau), ate his food, and smoked his month's stash of dope in the four days they spent together. They spent their time making love and listening to music on David's transistor radio. As long as everything proceeded smoothly, Mona was happy to stay with David, but she abandoned him when he was beaten up during the robbery of the chateau. In his testimony, David, seated in a box car on a freight train, tells the audience: "I thought she was the staying kind." He was hurt by Mona's abandonment, even though she never promised to stay. In one of their conversations, she even said that "Usually it [relationships] doesn't last two days for me."

David, lonely in his wanderings, expected that Mona was lonely too. He told her that sometimes he even considered himself the "wandering Jew," condemned to walk alone eternally. In Mona he saw a mate to join him in his wandering, but did not realise that she had no intention of wandering with anyone. He was hurt by her rejection.

In contrast, it is her other lover, Assoun, who rejects her. When Assoun meets Mona in the vineyard, he accepts Mona as she is. He invites her to stay with him and help him look after the vineyards while the other workers are away. For a short time Mona tries to work alongside Assoun, but her progress is slow and he asks her simply to try and keep up with him no matter how poorly her work is done. Eventually, Mona just sits and watches him work. In their relationship Assoun works and Assoun cooks; Mona simply exists. She shows him tenderness and affection, defends his worth to the manager's wife, and gradually grows to depend on his quiet company. When the other workers return, they tell Assoun that Mona must leave. He had accepted her, but the others cannot. According to Varda Assoun is "... the victim of the group." (7) Assoun wants Mona to stay, but he cannot force the group to accept her and he cannot reject the group; therefore, he must reject Mona.

During the time they spend together, Mona is happy. She asks Assoun questions about his life and about the other workers, and enjoys going with him into the vineyards. Unfortunately, he is not in a position to offer her more, and when the others reject her, he is powerless to let her stay.

The harshest rejection Mona faces in her journey is the one given by the Goatherd. In his own words he chose a "middle road between loneliness and freedom," when he decided to reject mainstream society but to keep a family. The morning after Mona's arrival his irritation with her begins to show. He thinks she has slept long enough so he makes a great ruckus to wake her. As they speak he learns that she lives for the complete freedom of the road, that she has no desire for anything. Over dinner one night Mona mentions that she would like to grow potatoes, so the Goatherd gives her a stretch of land to farm. He also moves her out of the house and into an abandoned trailer in the yard. To disguise her hurt at being moved away from him and his family, Mona exclaims "You three and the herd are a crowd" as she moves into her tiny 
new home. Once in her new home Mona forgets about her potato farm. She stays in her trailer reading, smoking and sleeping. The Goatherd, in frustration, finally kicks her off his property. He tells her it's not fair that all she does is sit around all day while he and his wife work. During the conversation when he asks her to leave, Mona tells the Goatherd that if she had the chances he has had (he has a Master's degree in Philosophy) she would not be living in the squalor in which he exists. 'You live in filth just like me, only you work more," she tells him.

Later when he offers his "testimony," (which immediately follows Mona's rape) the Goatherd says: "By proving that she's useless, she helps the system she rejects. That's not wandering, that's withering." The Goatherd is "... still in the thrall to the work ethic of the society which [he] affects to despise," ${ }^{(8)}$ and cannot abide Mona's laziness. According to Varda the Goatherd is "... the worst judge of all because he wants to be marginal but in his way. He doesn't accept other people."(9)

Through these five encounters testimonies from other witnesses are interspersed. During the episode that shows Mona and David together, Yolande directly addresses the viewer and says, in reference to them, "If they're dead it's disgusting, if they're asleep its cute," and a quick cut shows the couple sleeping. Also during this episode the chateau's caretaker tells the police that he does not believe the "camper" had anything to do with the robbery. After the Goatherd kicks her out, a middle-aged woman says she liked Mona because "She's got character." During the episode in which Mona travels with Madame Landier, a construction worker describes having seen her trying to warm herself by a fire and says: "To be all alone like that, I should have spoken to her." After the returning workers reject her, Assoun's foremen wonders "Where is she now? Poor girl so young." The last witness to offer his testimony is Assoun. He simply looks into the camera and shows the scarf Mona used to wear.

Through these interviews Varda has shown how each person Mona encountered was altered by meeting her. Her behaviour has led everyone she met to question her behaviour and her or his reaction to it. By

"... moving back and forth between normal people's lives and Mona's, [Varda] offers an implicit critique of respectable normality ... but Varda herself clearly does not see Mona's freedom as in any way enviable but rather as terrible, even if conventional lives, lived inside houses and comforts and couples, are also profoundly unappealing." ${ }^{(10)}$

\section{Notes}

1. Also translated as Vagabond.

2. Sandy Flitterman-Lewis, To Desire Differently: Feminism and the French Cinema (Chicago: University of Illinois Press, 1990), p. 314. (Quoting from Varda's press book for Sans toit ni loi).

3. Barbara Quart, "Agnes Varda: A Conversation," Film Quarterly (Winter 1986/87), p. 5.

4. Susan Barrowclough. "Sans toit ni loi (Vagabonde)." Monthly Film Bulletin. (April 1986), p. 120.

5. Quart, p. 7.

6. Quart, p. 8.

7. Quart, p. 10.

8. Sheila Johnstone, "Vagabonde," Films and Filming (May 1986), p. 41.

9. Quart, p. 10.

10. Barbara Koenig Quart. Women Directors: The Emergence of a New Cinema, (New York: Praeger, 1988), p. 144.

\section{References}

\section{Literature}


Armes, Roy. French Cinema. New York: Oxford University Press, 1985.

Armes, Roy. French Cinema Since 1946: Volume Two The Personal Style. New Jersey: A.S. Barnes \& Co., 1970.

Aude, Françoise. "Sans toit ni loi: La zone." Positif, 299 (January 1986), 64-65.

Barrowclough, Susan. "Sans toit ni loi (Vagabonde)." Monthly Film Bulletin, 53/627 (April 1986), 119-120.

Bergala, Alain. "La repousse." Cahiers du Cinéma, 378 (December 1985), 5-7.

Beylie, Claude. "Les chardons ardents d'Agnes Varda." Ecran, April 15, 1979, 5-6.

Bonnaire, Sandrine. "Au risque du tournage." Cahiers du Cinéma, 378 (December 1985), 9-10.

Coleman, John. "Cemetery Road." The New Statesman, 111/2876 (May 9, 1986), 32-33.

Cook, David A. A History of Narrative Film. New York: W.W. Norton \& Company, 1981.

Dazat, Olivier. "Marche funèbre." Cinématographe, 114 (December 1985), 11.

Dazat, Olivier. "Jouer à la belle étoile." Cinématographe, 114 (Dec. 1985), 13-15.

Dazat, O. \& G. Horvileur. "Agnès Varda de 5 à 7." Cinématographe, 114 (December 1985), 18-24.

Flitterman-Lewis, Sandy. To Desire Differently: Feminism and French Cinema. Chicago: University of Illinois Press, 1990.

Forbes, Jill. "Cold Venus: Vagabonde." Sight and Sound, 55 (Summer 1986), 209-210.

Gili, Jean A. "Venise 1985." Positif, 298 (December 1985) 49.

Giannetti, Louis. Understanding Movies. Englewood Cliffs: Prentice Hall, 1990.

Heck-Rabi, Louise. Women Filmmakers: A Critical Reception. Metuchen: Scarecrow Press, 1984.

Johnstone, Sheila. "Vagabonde." Films and Filming, 380 (May 1986), 41.

Kael, Pauline. "The current cinema: drifters, dopes and dopers." New Yorker, 62/13 (May 19, 1986), 98-101.

Kauffman, Stanley. "Lower Depths." New Republic, 3/724 June 2, 1986), 24-26.

Lejeune, Paule. Le Cinéma des femmes. Paris: Editions Atlas Lherminier, 1987.

Martin, Marcel. "Brève rencontre ... avec Agnès Varda." Ecran, 58 (May 5, 1977), 12-13.

Mayne, Judith. The Women at the Keyhole: Feminism and Women's Cinema. Bloomington: Indiana University Press, 1990.

Monaco, James. How to Read a Film: The Art, Technology, Language and History of Film and Media. New York: Oxford University Press, 1981.

Monaco, James. The New Wave: Truffaut, Godard, Chabrol, Rohmer, Rivette. New York: Oxford University Press, 1976.

Notes on Women's Cinema. Ed. Claire Johnston. London: Society for Education in Film and Television, 1973.

Quart, Barbara Koenig. Women Directors: The Emergence of a New Cinema. New York: Praeger, 1988.

Ranvaud, Don. "Travellers' tales." Monthly Film Bulletin, 53/628 (May 1986), 160.

Simon, John. "Ends and Beginnings." National Review, 38/15 (August 15, 1986), 49-51.

Toubiana, Serge. "42e mostra de Venise." Cahiers du Cinéma, 376 (Oct. 1985), 11-12.

Varda, Agnès. "Un jour sous le ciel." Cahiers du Cinéma, 378 (Dec. 1985), 12-15. 
World Film Directors: Volume Two 1945-1985. Ed. John Wakeman. New York: H.W. Wilson, 1988.

\section{Author Information}

Michal QUIGLEY graduated in film studies from the University of Waterloo, Ontario, Canada. She worked as a television producer in Halifax, Nova Scotia. 